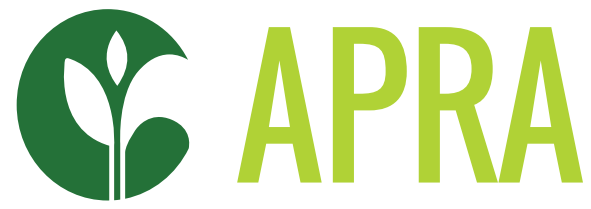

Agricultural Policy Research in Africa

\title{
LONG-TERM CHANGE, COMMERCIALISATION OF COCOA FARMING, AND AGROECOSYSTEMS AND FOREST REHABILITATION IN GHANA
}

Kojo Amanor, Joseph Yaro and Joseph Teye 


\section{TABLE OF CONTENTS}

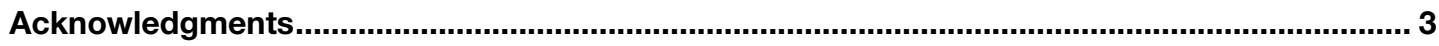

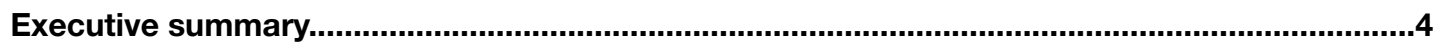

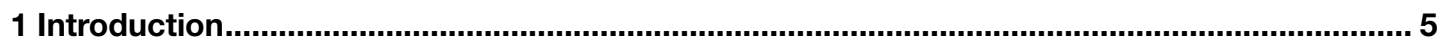

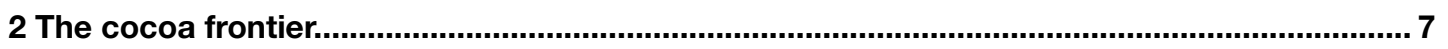

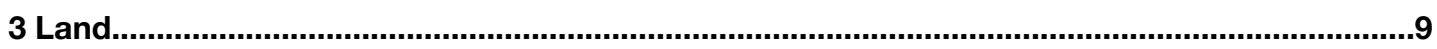

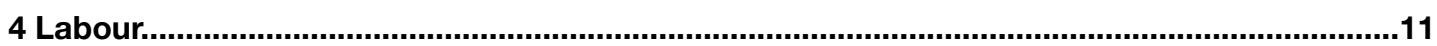

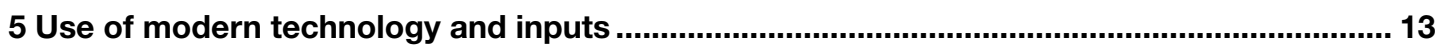

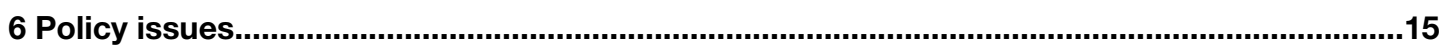

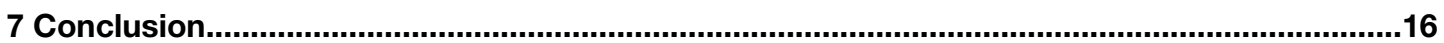

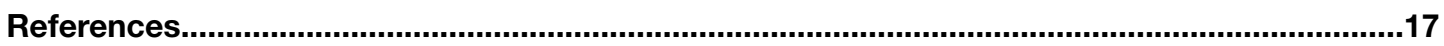

\section{List of tables}

Table 4.1. Land ownership in Suhum-Ayensuano and Juaboso ........................................... 10

Table 4.2. Nature of access to land on cocoa plantations ................................................ 10

Table 5.1. Percentage of men and women farmers using hired labour................................ 11

Table 6.1. Use of inputs in Suhum-Ayensuano and Juaboso ............................................... 13

Table 6.2. Comparison of yields of planted hybrid and non-hybrid cocoa .......................... 14

\section{List of figures}

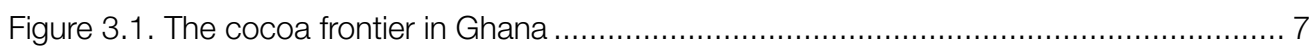




\section{ACKNOWLEDGEMENTS}

We are thankful to the field assistants who helped administer questionnaires and interviews: David Atombire Adumbire, Ben Michael Awenam, Nii Adotei Emmanuel Baddoo, Emmanuel Bruku, Fauziyatu Moro, Fobil Ntilam, Alexander Nii Adjei Sowah, Dorothy Takyiakwaa, Dzifa Torvike, and Worlali Torvike; and the farmers and others in the Ayensuano, Juaboso and Suhum municipalities, who were kind enough to give up their time to our questioning.

Kojo Amanor is a professor at the Institute of African Studies, University of Ghana. Joseph Awetori Yaro is a professor in the Department of Geography and Resource Development, University of Ghana. Joseph K. Teye is also a professor in the Department of Geography and Resource Development at the University of Ghana.

This working paper is funded with UK aid from the UK government (Foreign, Commonwealth \& Development Office, formerly the Department for International Development). The opinions are the authors and do not necessarily reflect the views or policies of the Institute of Development Studies or the UK government. 


\section{EXECUTIVE SUMMARY}

Cocoa production has a long history in Ghana, originating in the late nineteenth century. Since then, cocoa production has seen significant changes. Originally, cocoa was cultivated in newly cleared forests in which many forest trees were preserved as shade trees. Cocoa is ideally suited to these conditions and produces high yields with minimum investment in labour and inputs. However, over time, as the forest conditions change, the cost of cultivating cocoa has increased and yields have declined. As long as new forest frontiers exist, farmers have continued to move into these areas, which have displaced older areas of cultivation, since the costs of production are significantly lower in the new frontiers. In recent years, however, new forest frontiers have declined and most cocoa farmers have been forced to rehabilitate and replant cocoa in open land.

Cocoa disease has been another challenge faced by farmers. By the late 1930s cocoa was threatened by a serious epidemic of swollen shoot virus disease. This led to government interventions in the late 1950s to introduce new hybrid varieties. However, this has not solved the problem of diseases and resulted in diminishing returns as farmers increased expenditure on agrochemicals. While inputs have been developed to raise yields, many farmers cannot afford them. The government has addressed this, by subsidising inputs and introducing mass spraying campaigns, but these programmes do not reach all farmers. The clearing of forest trees, in an attempt to intensify yields, stresses the cocoa trees and reduces their productive life. This has resulted in a recent focus on promoting cocoa agroforests. While cocoa output has increased significantly in recent years, yields continue to be low, suggesting that this has resulted from the expansion of area under cocoa and rehabilitation of more land, rather than the effective use of inputs.

This study examines the rational of frontier development; changes in land relations, labour relations and use of technology; and the impact of these factors on different categories of farmers, including women and youth. This is developed through two comparative case studies drawn from the older cocoa frontier of the Eastern Region, and the more recent frontier of Western North Region.

The study found that, as a consequence of land shortage and relatively high production costs, there are significant barriers of entry for many small farmers including women and youth. However, the high costs of production, low returns and high incidence of disease also discourage large farmers from accumulating capital in cocoa. High labour and agrochemical costs often result in low use of fertilisers, which are critical to improvement in yields of hybrid varieties. Although new technologies have been introduced to tackle cocoa disease, these interventions have not successfully addressed this problem. Thus, present initiatives towards developing more sustainable cocoa based on forest conservation, agroforestry and tree planting also need to address the problems of pests and diseases within an ecological framework, and work to reduce reliance on costly and harmful agrochemicals. 
Cocoa cultivation in Ghana originated in the late nineteenth century. This long history provides a unique opportunity to trace long-term patterns of agricultural commercialisation that precede the dominant models of agricultural modernisation, which are rooted in an ahistorical dualist framework of a stagnant traditional sector and a dynamic modern sector. Tracing the patterns of development within the cocoa sector provides the opportunity to develop a long-term perspective on the processes of agricultural commercialisation within Africa. This paper investigates the long-term changes that have occurred within cocoa production in Ghana, which define a particular path of agricultural commercialisation. It examines the intensification of agricultural production, the adoption of high-input technology, the land relations, the use of hired labour, and family relations in production. The changing relations and factors of production are examined against the backdrop of environmental factors, reflected in the rapid colonisation of new forest lands by farmers, and mounting ecological problems of disease and declining soil fertility in old areas of cultivation. New technology options to address these problems provide an expensive option that most farmers can ill-afford since they operate on very narrow profit margins. The cycles of boom and bust and periodic international price slumps that characterise international cocoa markets also undermine consistent investment by farmers in technology, leading to a movement of large-scale farmers out of cocoa. Thus, cocoa production is beset by tensions related to ecological problems and market instability.

The early development of cocoa is associated with the emergence of land and labour markets, which facilitated commercial production. It has involved pioneer frontier movements in which production in new regions displaces the older regions and leads to migrations of farmers and labourers to the new frontier, extending land and labour markets. Over time, the rapid expansion of cocoa production results in ecological crises in which the rise of monocultures leads to problems of disease and difficulties of reestablishing new plantations when the original forest cover disappears. Changes in cocoa production in recent years are associated with shifts from extensive production based on movement to new frontier areas, to the increasing use of new hybrid varieties, synthetic fertilisers and agrochemicals in old production areas. This is reflected in a shift from accumulation of profits based on cultivation of large areas, to more intensive production on much smaller plots of land. Cocoa is well suited to forest conditions and in newly opened up forests it provides high yields for minimal investments in labour. This encourages the rapid conversion of forest into cocoa plantations and investments of land profits into newly opened up forest areas. This leads to a rapid commodification of land and labour, with farmers becoming reliant upon hired labour to supplement family labour. Eventually, the favourable conditions for cocoa production decline in old frontier areas, and disease epidemics begin to emerge. Faced with the high costs of replanting cocoa in old areas, many farmers prefer to acquire land in new forest areas and move their production to these areas. In old production areas, the increasing labour requirements and scarcity and costs of land result in intensification of production by cocoa farmers on smaller holding. This also arises from increasing land shortage and demand for land. The persistence of disease epidemics and problems with replanting has led to government research services developing new hybrid varieties and the use of fertilisers and agrochemicals to contain disease and address declining yields. This results in two types of intensification on cocoa farms: the first involves the increased use of labour based on farmers' own knowledge systems of cocoa and forest management, and the second is based on following extension services input recommendations for hybrid cocoa cultivation. However, the existence of new frontier land creates economic pressures on technical innovations in older frontier areas. The cocoa sector, throughout the world, tends to be characterised by cyclical movements of alternating periods of booms and bust (Ruf, 2010), and the opening up of new forested areas leads to surplus production that encourages price slumps and low profit margins. This discourages investments in new technology.

This paper examines the interactions between ecological factors, markets, access to land, labour and technology, and the social relations of production that shape the processes of commercialisation within the cocoa sector within a historical framework. It 
investigates the ways in which these factors have influenced a major shift within cocoa from extensive farm cultivation with relatively low investments in labour to a dominantly smallholder activity with relative high investments in labour and technology. Although this results in smallholders dominating the cocoa sector, there are significant barriers to entry, including scarcity of land and high production costs, that prevent many poorer and more marginalised farmers, including women and youth, from participating independently in cocoa. The paper examines the process of frontier development in cocoa, the patterns of commodification of land and labour, the adoption of modern technical innovations, and the contemporary policy discourses.

This paper draws upon field research carried out in the Suhum and Ayensuano districts (subsequently referred to as Suhum-Ayensuano) of the Eastern Region and the Juaboso district in the Western North Region, bordering Côte d'Ivoire. Suhum-Ayensuano is one of the oldest cocoa-growing areas in Ghana, in which farmers began purchasing land on a large scale in the early 1900s. By the late 1930s, swollen shoot disease emerged as a major problem and by the 1950s, farmers were forced to cut out diseased trees and begin replanting cocoa. Faced with high labour costs for replanting cocoa, many farmers chose to migrate to the Western Region to acquire new forest land. Cocoa began to be cultivated in Juaboso on a significant scale from the 1950s to 1970s. Disease problems and replanting are currently beginning to emerge as major issues. The differences between these two areas provide insights into the process of commodification and intensification of cocoa production. The study draws on a quantitative survey of 517 farmers, of which 35 per cent were women; and in-depth interviews with 91 farmers (including 32 women) on their perceptions of change in cocoa, and nine focus group discussions. 


\section{THE COCOA FRONTIER}

Ghanaian farmers began to cultivate cocoa before the imposition of colonial rule in the late nineteenth century. They built upon earlier forms of commercial agriculture that developed before the 1830s in the export of palm oil to Europe. This created both a class of wealthy farmers that had accumulated capital and land in agriculture, and the emergence of land markets. This facilitated the rapid expansion of farmers adopting cocoa cultivation into vacant forestland, and investments in expanding areas under cultivation by acquiring more land and hiring labour. This has facilitated a process of pioneer frontier movement through which cocoa cultivation has rapidly expanded through the forest zone. By 1911, the Gold Coast emerged as the world's largest cocoa producer. While large-scale farmers have often been important in establishing cocoa in new forest areas, many smallholder farmers have also taken up cocoa cultivation.
The history of commercial development in Ghanaian cocoa is well documented (Hill, 1963; Amanor, 1994; Austin, 2005). The historical development of cocoa was not dependent upon adoption of new technology, but essentially grew out of the historical practices of Ghanaian farmers and their management of forest environments. It involved the incorporation of a new crop into existing farming practices, and indigenous institutional innovations in land purchases and labour markets rooted in the domestic economy rather than adoption of externally defined practice. Farmers took advantage of forested conditions in which cocoa thrives to gain windfall yields. While this made use of the considerable ecological knowledge of farmers, it was based on the expansion of monocultural production and opening up of new forests. This has resulted in long-term environmental consequences. Cocoa farmers continually moved to new forest frontiers

Figure 3.1. The cocoa frontier in Ghana

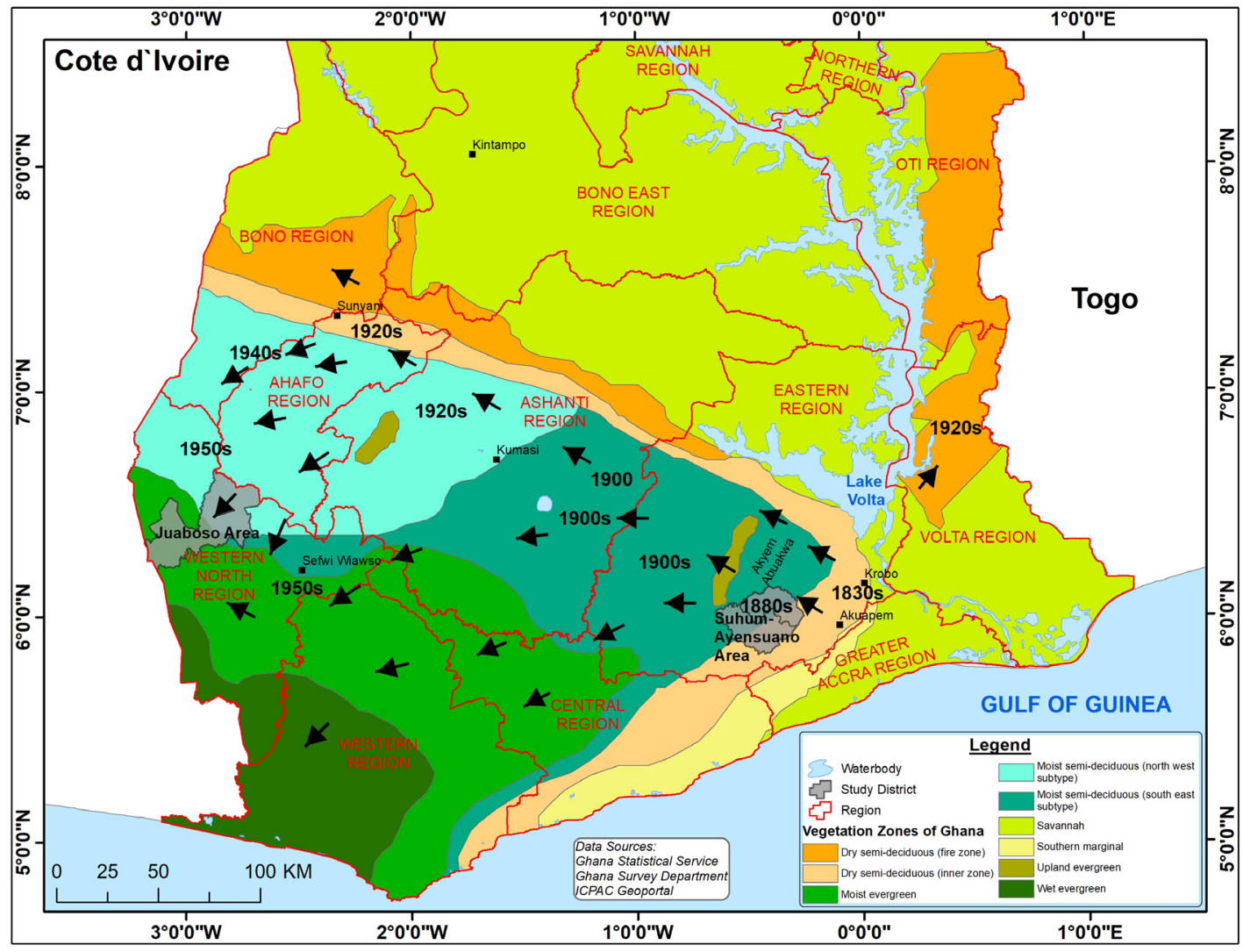

Source: () Ghana Statistical Services and Amanor (1994), adapted by authors' 
where yields were heaviest and production costs less. In the old production districts, cocoa has become increasingly vulnerable to disease and pest epidemics. This has included swollen shoot disease, capsids, and in recent years, black pod disease. From the 1950s, swollen shoot became a major problem in the Eastern Region, which resulted in a major campaign to cut out infested trees (Danquah, 2003). The declining fertility of old forest areas, as well as the increasing expenditure of labour in weeding secondary bush and mistletoe infections of cocoa, have also compounded disease problems. As a consequence, the replanting of cocoa in old plantations and secondary bush has led to a significant decline in yields and returns to capital, and higher expenditure on labour and inputs (Ruf, 2010). This has resulted in the decline of cocoa production in the Eastern and Ashanti Regions and the shift to the Western Region as the main production zone from the 1950-1970s. New hybrid varieties better adapted to the changing conditions have been introduced by the cocoa services to deal with these problems, but successful cultivation of these depends upon a regime of applying synthetic fertilisers and agrochemicals.

As long as uncultivated forestland exists, farmers prefer to move to the new frontier to cultivate cocoa rather than rehabilitate old plantations. The opening up of new frontiers results in surplus production of cocoa, and the international price for cocoa adjusts accordingly, setting prices to the cost of production in newer frontiers and undercutting cost of production in older areas, thus intensifying the process of frontier colonisation. Historically, this has resulted in global shifts in the production of cocoa from South America in the nineteenth century, to the Gold Coast in the early twentieth century and to the Côte d'Ivoire in the 1970s. By the late 1990s, as the forest frontier disappeared in Côte d'Ivoire, new competition emerged from Brazil, Indonesia and Malaysia. During the 1990s, innovations by smallholder farmers in Côte d'Ivoire and Indonesia led to optimistic assessments of the future of new technologies in cocoa farming (Ruf, 2010). But these developments have floundered and presently, smallholder cocoa farmers throughout the world are confronted by ecological crises, high costs of production, disease problems, and increasing impoverishment. Many smallholder farmers, throughout the world, find the shift to hybrid cocoa and inputs difficult to make, with the results that many farmers fail to take up these new recommendations and either struggle to continue producing low yields of cocoa, or shift into the production of other export or food crops when viable. 
Land relations within the cocoa belt have been shaped by the existence of three distinct types of farmers. The first consists of large migrant farmers, who Hill (1963) has characterised as capitalist farmers. These have historically acquired large tracts of land and reinvested profits in the purchase of new land. The second consists of the autochthonous farmers who hold rights to land as citizens and members of lineages. They use family land to make cocoa plantations or clear uncultivated forestland. They do not have to purchase land. This includes a large number of smallholder cultivators with small plots of land, but also local farmers who are able to accumulate and expand their holdings and supplement family labour with hired labour. The third stratum consists of poorer migrants who cannot afford to purchase land and move to the main cocoaproducing areas as labourers, where they may also enter into sharecropping contracts with landowners. The existence of migrant large farmers investing in land and migrant labour often act as a catalyst for the opening up of commercial agriculture in forest frontier areas, where constraints of the indigenous capital formation and lack of labourers hinder the development of cash crop farmers. Movement of migrant labour into these areas allows local landowners and chiefs to begin to cultivate their own cocoa with labourers, and to hire out land under sharecrop contracts. The movement of labour into these areas enables local landowners to capitalise their lands and transform sharecropping rents into claims over portions of cocoa plantations.

The earliest documented land sales occurred in southeastern Ghana in the early nineteenth century when wealthy trader-farmers began acquiring large oil palm estates in the Krobo and Akuapem areas (Amanor, 1994). Oil palm was the first significant export crop traded with Europe. By the 1860s, world market prices declined for palm oil as competition grew from southeastern Asian producers. Declining oil palm prices resulted in farmers shifting from oil palm to cocoa. While some of the oil palm plantations were converted to cocoa, large numbers of aspiring cocoa farmers moved into wetter forest areas in which cocoa thrived, purchasing land from the chiefs, and moving with their extended families to these new areas to produce cocoa. They subsequently allocated and parcelled out the large plots they had acquired to dependents that had helped them in clearing the forest and planting cocoa (Hill, 1963).

Although large forested lands were sold to migrant farmers, this has not led to the significant development of land markets. In the early stages of the development of cocoa farming by migrants, labour was often very scarce. The land purchasers often relied on their extended kin to develop their plantations and these family members acquired interests and rights in the land, which was subsequently allocated to family members. Thus, individually acquired property was transformed back into family land. The continued scramble for land in new frontiers and the uptake of cocoa farming by smallholders within localities resulted in the increasing shortage and scarcity of land. The high demand for land resulted in increasing values for land, which made farmers reluctant to sell surplus land. As an influx of labour into new frontier areas occurred, landowners in the areas began to transact land with farmers on sharecrop contracts, which enabled them to continue to control the land. These sharecrop contracts occur as a half or a one-third/two-thirds division between landlord and tenant, with differences in the contract emerging over time in relationship to the scarcity of land. In some sharecropping systems, the tenant is responsible for managing the plantation and provides a share of proceeds to the landowner, which varies between a third share and a half share. In other instances, the plantation is divided into half or two-thirds share given to the landlord when it starts fruiting and the landlord and tenant are responsible for managing their specific share.

As land becomes scarce, not all family members are able to gain access to family land. The shortage of family land frequently results in it becoming subject to sharecrop tenancies. Those family members who gain access to land to cultivate cocoa in land-hungry lineages are often required to provide a share of their yield to the lineage elder for the upkeep of the lineage. This may be an informal arrangement without the exact nature of the contribution defined, or a more formalised sharecrop tenancy. Sharecropping also emerges in the context of the rehabilitation of old plantation; 
landowners who lack the capital or labour to reestablish their cocoa plantation may elect to release it to a sharecrop tenant with the labour or capital to undertake the task of replanting. In some instances, the farmer contracting out the land is elderly, and the land is contracted with a younger and stronger family member with the capability of farming the land. This arrangement is also important for independent women farmers with access to small plots of land, but a lack of capital to hire labour, and the small cocoa plantation becomes significant in providing income for the care of young dependents. Thus, sharecropping emerges both in the contexts of land scarcity, and lack of labour and capital.

Presently, the two dominant forms of access to land are family land and sharecropping. In the survey of farmers, only 5 per cent of farmers had gained their land through direct purchase while 68 per cent cultivated their cocoa on family land and 21 per cent sharecropped. There were also significant differences in access to land in Suhum-Ayensuoano and Juaboso. In Suhum-Ayensuano, 42 per cent of interviewed farmers cultivated sharecrop land and 53 per cent family land. In Juaboso, 80 per cent of farmers cultivated family land and only 5 per cent sharecropped (see Table 4.1). The higher scarcity of land in Suhum-Ayensuano is also reflected in the size of land holdings. Sixty-five per cent of farmers in Suhum-Ayensuano had holdings under 2.5ha as compared to 35 per cent of farmers at Juaboso. The shortage of land adversely impacts upon women. For example, 35 per cent of women cocoa farmers at Suhum-Ayensuano held less than tha of land as compared to 12 per cent of men. In Juaboso, 10 per cent of women farmed less than tha of land as compared to 4 per cent of men (Table 4.2).

Scarcity of land results in many farmers having fragmented plots, or results in increasingly costly access to land in which farmers can give up to 50 per cent of their yield as sharecrop rent. This results in less capital for investment in labour and inputs. Since most farmers gain access to land through family relations or sharecropping, security of land tenure and equitable access are not easily addressed through reforms that seek to strengthen individual property rights. Stronger individual property rights related to expansion of land markets can, in theory, enable those most in need of land for farm expansion to acquire it on markets and lead to a 'realistic' recognition that, given the expansion of population, not all rural citizens can have access to land. However, experience from other sectors suggests that this may undermine the rights of the rural poor, and chiefs may seize the opportunity to gain further rents from land with less clearly defined individual land rights to aspiring commercial farmers with capital (Yaro, 2010; Boafo and Lyons, 2019). This may further exacerbate the land rights of women and other smallholder farmers who often rely on derived rights and sharecrop leases to gain access to land rather than on their claims to individually-owned property. This may also lead to the conversion of land from cocoa to other more capitalised sectors such as rubber that are more amenable to large-scale commercial investments.

Table 4.1. Land ownership in Suhum-Ayensuano and Juaboso

\begin{tabular}{|l|l|l|l|l|}
\hline Hectares & $\begin{array}{l}\text { Suhum-Ayensuano } \\
(\%)\end{array}$ & Juaboso (\%) & Total (\%) & No. of farmers \\
\hline Under 1ha & 20.3 & 5.8 & 12.6 & 65 \\
\hline $1-2.4$ ha & 44.8 & 30.4 & 37.1 & 192 \\
\hline $2.5-4$ ha & 21.6 & 22.1 & 21.9 & 113 \\
\hline $4.1-8$ ha & 11.2 & 31.5 & 22.1 & 114 \\
\hline Over 8ha & 2.1 & 10.2 & 6.3 & 33 \\
\hline Total & 241 & 276 & 517 & 517 \\
\hline
\end{tabular}

Source: Authors' own

Table 4.2. Nature of access to land on cocoa plantations

\begin{tabular}{|l|l|l|l|l|}
\hline Source of land & $\begin{array}{l}\text { Suhum-Ayensuano } \\
(\% \text { of farm plots) }\end{array}$ & $\begin{array}{l}\text { Juaboso } \\
(\% \text { of farm plots) }\end{array}$ & $\begin{array}{l}\text { Total } \\
(\% \text { of farm plots) }\end{array}$ & No. of farm plots \\
\hline Family land & 52.4 & 79.8 & 68.0 & 669 \\
\hline Purchased & 4.7 & 5.5 & 5.2 & 51 \\
\hline Sharecrop & 42.2 & 5.0 & 21.0 & 207 \\
\hline Other & 0.7 & 9.6 & 5.8 & 57 \\
\hline No. of farm plots & 424 & 560 & 984 & 984 \\
\hline
\end{tabular}

Source: Authors' own 
Labour has increasingly become a scarce and expensive factor of cocoa production. During its heyday, from 1920s-1950s, cocoa farmers in Ghana were able to draw upon a widely available source of migrant labour from Burkina Faso, Mali and Niger, and northern Ghana. This complemented family labour. Payment for labour was often delayed until after harvest through the annual labourer and abusa labourer systems. The annual labourer was provided with a lump sum after harvest and food and access to land to cultivate food crops during the farming season. The abusa labourer was provided with a third of the cocoa crop harvest proceeds. While the abusa labourer system superficially resembles sharecropping of land, it is an arrangement made with an individual seeking work as a labourer who lacks capital to invest in creating a plantation. The labourer is hired to work for a minimum of a year and is remunerated for their labour with a third share of the harvest. By the 1970s, both of these labouring systems became scarce as many of the migrants from Sahelian countries relocated to Cộte d'Ivoire. These two labour systems have largely been replaced by hired daily labour and contract labour (hired to carry out a particular task or to clear a specific area of land). The long distant Sahelian migrant has largely been replaced by local youth labour. In the SuhumAyensuano area, the main labourers are drawn from the local area, but in Juaboso, there is still a significant element of migrant labourers from northern Ghana and Togo. These migrants are sometimes organised into labour gangs that move between settlements, providing labour on credit, with the labourers returning after the harvest season to be paid. This illustrates the scarcity of capital at the disposal of many farmers for hiring labour.

The rise of casual labour reflects both the scarcity of land among the youth and demand for labour among farmers. These factors are interrelated since scarcity of family land results in young farmers looking elsewhere for land or for alternative occupations. As a result of the movement of youth away from family land, lineage elders are no longer able to draw upon the labour of their descendants on the farm and become increasingly dependent upon hiring labour or sharecropping land out. The demand for labour creates avenues for the youth to gain income as labourers. As a result of higher scarcity of land and lower access of youth to family land, farmers at Suhum-Ayensuano are more dependent upon hired labour than those at Juaboso, who still allocate land to their children and count upon their help in farming. While 73 per cent of farmers in the two areas hired labour, 81 per cent of Suhum-Ayensuano farmers hired labour as compared to 65 per cent at Juaboso. In Suhum-Ayensuano, 84 per cent of women hire labour as compared to 80 per cent of men, and at Juaboso, 68 per cent of women hire labour as compared to 63 per cent of men. When broken down to the various types of labour hired, the most significant difference is in land clearance, which is hired by 48 per cent of farmers at Suhum-Ayensuano as compared to only 19 per cent of farmers at

Table 5.1. Percentage of men and women farmers using hired labour

\begin{tabular}{|c|c|c|c|c|c|c|c|c|c|c|}
\hline \multirow{2}{*}{$\begin{array}{l}\text { Type of } \\
\text { labour }\end{array}$} & \multicolumn{3}{|c|}{ Suhum-Juaboso Total } & \multicolumn{3}{|c|}{ Juaboso (\%) } & \multicolumn{3}{|c|}{ Total sample (\%) } & \multirow{2}{*}{$\begin{array}{l}\text { Total } \\
\text { no. of } \\
\text { farmers }\end{array}$} \\
\hline & Male & Female & Total & Male & Female & Total & Male & Female & Total & \\
\hline $\begin{array}{l}\text { Land } \\
\text { clearance }\end{array}$ & 47.6 & 49.4 & 48.1 & 12.8 & 19.2 & 15.2 & 29.8 & 32.0 & 30.6 & 517 \\
\hline Weeding & 76.2 & 80.5 & 77.6 & 58.7 & 65.4 & 61.2 & 67.3 & 71.8 & 68.9 & 517 \\
\hline Pruning & 42.7 & 48.4 & 44.8 & 38.4 & 44.2 & 40.6 & 40.5 & 46.4 & 42.6 & 517 \\
\hline Harvesting & 66.5 & 72.7 & 68.5 & 48.8 & 50 & 49.3 & 57.4 & 59.7 & 58.2 & 517 \\
\hline $\begin{array}{l}\text { No. of } \\
\text { farmers }\end{array}$ & 164 & 77 & 241 & 172 & 104 & 276 & 336 & 181 & 517 & \\
\hline
\end{tabular}

Source: Authors' own 
Juaboso (Table 5.1). This suggests that the increasing fragmentation of land holdings in Suhum-Ayensuano, and increasing recourse to sharecropping, results in a decline of extended reciprocal household labour that can be called upon to help with land clearance. Suhum-Ayensuano farmers have significantly smaller holdings than their Juaboso counterparts, yet they depend more upon hired labour.

As land becomes scarce, more farmers access land through sharecropping, and lineages are unable to draw upon the labour of family youth to the extent they did in the past. Many members of the family youth are also working outside of the family land as labourers. However, labour has also become increasingly expensive since farmers can no longer draw upon cheap migrant labour as they did in the past, and local youth are dependent upon labouring for providing their income, since they no longer have access to family land. As labour costs increase, larger numbers of poorer farmers are unable to meet the costs of rehabilitating their farms and release land to sharecrop tenants. This reinforces the commoditisation of land and labour relations, and leads to increasing costs of production and monetisation of labour. 


\section{USE OF MODERN TECHNOLOGY AND INPUTS}

The increasing relative costs of access to land and labour in comparison to the returns to cocoa production result in decreasing profit margins for farmers to afford agricultural inputs. Faced with making choices between allocating resources to labour, agrochemicals and fertilisers, most farmers give priority to labour and agrochemicals over fertilisers, since overgrown weeds, mistletoe and disease have the most devastating impacts on yields. In a bid to encourage farmers to take up hybrid seeds and inputs, the cocoa services and programmes run by cocoa transnational corporations, such as Cargill's Cocoa Promise and Nestlé's Cocoa Plan, provide free packages of technology to farmers, mass spraying campaigns, and subsidised inputs (Odijie, 2018). This has resulted in some adoption of modern technologies, but uptake is often influenced by free access, which does not guarantee sustained use in the future. This can have negative consequences, for instance, where farmers adopt hybrid varieties and then clear more shade trees to accommodate the hybrid varieties, but fail to use fertilisers because of the cost.
In the long-term this may result in lower yields, higher disease, increased deforestation, and cocoa trees that lack robustness and rapidly become unproductive in comparison with the older varieties. Farmers frequently select hybrid seeds for planting from trees on the farms, resulting in poor-yielding cocoa that does not reflect the characteristics of the parent. Information on the recommended cultural practices is often transmitted to farmers in ways they do not understand clearly. Extension recommendations are uniform and not finely tuned to the real world conditions that different categories of farmers face. They do not reflect the capital and assets available to many farmers, or the high costs of inputs in relation to the international prices paid for cocoa, particularly during cycles of downturn.

Only 16 per cent of farmers interviewed used chemical fertilisers, including 25 per cent at Suhum-Ayensuano and 9 per cent at Juaboso (only 12 per cent of farmers actually purchased fertilisers on the market, including 16 per cent of Suhum-Ayensuano farmers and 8 per cent of Juaboso farmers - the other farmers gained

Table 6.1. Use of inputs in Suhum-Ayensuano and Juaboso

\begin{tabular}{|c|c|c|c|c|c|}
\hline $\begin{array}{l}\text { Percentage of farmers } \\
\text { using or purchasing } \\
\text { inputs }\end{array}$ & District & Male (\%) & Female (\%) & Total (\%) & $\begin{array}{l}\text { No. of } \\
\text { farmers }\end{array}$ \\
\hline \multirow[t]{3}{*}{ Purchase of fertilisers } & Suhum-Ayensuano & 17.7 & 11.7 & 15.8 & 241 \\
\hline & Juaboso & 7.0 & 10.6 & 8.3 & 276 \\
\hline & Total & 12.2 & 11 & 11.8 & 517 \\
\hline \multirow[t]{3}{*}{ Use of fertilisers } & Suhum-Ayensuano & 29.9 & 14.3 & 24.9 & 241 \\
\hline & Juaboso & 7.6 & 11.5 & 9.1 & 276 \\
\hline & Total & 18.5 & 12.7 & 16.4 & 517 \\
\hline \multirow[t]{3}{*}{ Purchase of agrochemicals } & Suhum-Ayensuano & 70.7 & 59.7 & 67.2 & 241 \\
\hline & Juaboso & 97.1 & 94.2 & 96.0 & 276 \\
\hline & Total & 84.2 & 79.6 & 82.6 & 517 \\
\hline \multirow[t]{3}{*}{ Use of agrochemicals } & Suhum-Ayensuano & 81.7 & 75.3 & 79.7 & 241 \\
\hline & Juaboso & 97.7 & 96.2 & 97.1 & 276 \\
\hline & Total & 89.9 & 87.3 & 89.0 & 517 \\
\hline \multirow[t]{3}{*}{ Use of modern hybrids } & Suhum-Ayensuano & 43.9 & 35.1 & 41.1 & 241 \\
\hline & Juaboso & 93.6 & 97.1 & 94.9 & 276 \\
\hline & Total & 69.3 & 70.7 & 69.8 & 517 \\
\hline
\end{tabular}

Source: Authors' own 
their fertilisers from free distribution in projects). Agrochemicals, in contrast, are used by 89 per cent of farmers including 97 per cent at Juaboso and 80 per cent at Suhum-Ayensuano. While government freely provides agrochemicals in mass spraying campaigns, 83 per cent of farmers purchased additional agrochemicals, including 96 per cent of Juaboso and 67 per cent of Suhum-Ayensuano farmers (Table 6.1).

Data collected on estimated yields per hectare suggested that farmers on the smaller holdings achieved the highest yields. Eleven per cent of cocoa farms of less than 2ha and 7 per cent of farms of between 2-4.99ha yielded $800 \mathrm{~kg}$ or more of cocoa per ha, while no farms of 5ha and above achieved comparable yields. A significantly higher number of farmers in Suhum-Ayensuano achieved these yields than in Juaboso. Eleven per cent of farms at Suhum-
Ayensuano and 3 per cent of farms at Juaboso with less than 2 ha gained yields of $800 \mathrm{~kg}$ and above per ha. Thirteen per cent of farmers at Suhum-Ayensuano and 2 per cent at Juaboso with between 2-4.99 gained $800 \mathrm{~kg}$ or more per ha. There was no correlation between use of hybrids and yield. Twelve per cent (17 farmers) of farms planted with non-hybrids achieved yields of over $800 \mathrm{~kg} / \mathrm{ha}$, while 5 per cent (17 farmers) of farms planted with hybrids also achieved similar yields (see table 5). While 5 per cent of farmers planting hybrids achieved this yield through the use of modern technology, a comparable number of farmers gained similar yields without using hybrids and synthetic inputs, presumably through investment in labour. However, the vast majority of farmers fail to achieve high yields and to follow the official recommendations for input application.

Table 6.2. Comparison of yields of planted hybrid and non-hybrid cocoa

\begin{tabular}{|l|l|l|l|}
\hline Cocoa yield $(\mathrm{kg} / \mathrm{ha})$ & No hybrid $(\%)$ & Planted hybrids (\%) & Total (\%) \\
\hline Less than 400kg/ha & 72.2 & 83.7 & 80.3 \\
\hline 401-800kg/ha & 16.0 & 11.5 & 12.8 \\
\hline Over $800 \mathrm{~kg} / \mathrm{ha}$ & 11.8 & 4.9 & 6.9 \\
\hline Total & 144 & 349 & 493 \\
\hline Pearson chi2 $(2)=10.3935 \mathrm{Pr}=0.006$ & & & \\
\hline
\end{tabular}

Source: Authors' own 


\section{POLICY ISSUES}

The dominant policy focus in the cocoa industry has been intensification of production through the use of modern hybrids and input technologies. Many farmers are faced with high costs of producing and rehabilitating cocoa in areas characterised by loss of forest and the domination of secondary bush. The cultivation of cocoa monocultures in these conditions require much higher expenditures on labour and inputs than farmers are accustomed to. The increasing costs of production are not adequately reflected in the prices paid to farmers, and in the cyclical fluctuations in prices. While government has stepped in to subsidise some of the cost of this expenditure, particularly in relation to hybrid seed production and agrochemicals, these are also high costs for the state to bear, in which the state is in danger of subsidising the costs of production to the benefit of international corporations rather than cocoa farmers, given serious allegations of impoverishment within the cocoa industry (Odijie, 2018).

The early successes of cocoa cultivation has resulted in a large demand for land, increasing scarcity of land, and the rise of sharecropping as a way of landlords extracting rent from the cocoa sector. The movement of cocoa to new forest frontiers has also resulted in the movements of migrant labour to these areas, creating scarcity of labour in old frontier areas. Disease also becomes a major problem in old frontier areas. The response of government has been to promote hybrid cocoa and high inputs. However, these have not solved the problems of disease and many farmers have not been able to afford the escalating costs of the new technology. This has resulted in stagnant or declining yields and higher costs of production. Since these higher costs are not reflected in the international price of cocoa, this results in impoverishment among cocoa farmers. These high costs of production also create large problems of access to land for women and youth and the rural poor, and pressures to release cocoa land to others on sharecrop arrangements, since they are unable to afford costs of production. Despite the high costs of inputs and labour, many poor farmers continue to produce cocoa and see benefit in its production in comparison to other crops, since they have few viable options. This includes a significant number of elderly and women farmers who derive incomes from leasing out existing cocoa plantations that they cannot afford the labour costs of maintaining. Ownership of a cocoa farm provides more security in claims on land, than food cropping. Thus, many farmers continue to cultivate low-yielding cocoa because they cannot afford to upgrade their production, because new technology does not necessarily convert into significant improvements in livelihoods or solve disease problems, and because they do not have viable options.

A recent concern in the cocoa sector has been to address issues of deforestation. The cocoa sector is working together with the forestry sector to encourage tree planting within cocoa farms, and develop more diversified cocoa agroforests in which farmers can derive economic benefit from trees. However, the dominant narratives within recent cocoa agroforest initiatives continues to be one of intensification through the use of inputs to increase yield and discourage farmers from extending their plantations (Gockowski and Sonwa, 2011). There is little reflection on the problem of disease and the impact of use of increasing agrochemicals on the environment and human health. This approach ignores recent scientific research on cocoa agroforests that attempt to promote more diverse farming systems and use less agrochemicals (Schroth and Harvey, 2007), and the long history of critical research by entomologists on cocoa disease and pests, which link disease to ecological problems and point to the significance of integrated pest management approaches to cocoa (Collingwood 1971; Padi and Owusu 1998).

Alongside options of creating a high-input high-yield cocoa production for more commercial farmers with capital, there is the need to create alternative options for poorer farmers that focus less on inputs and yield and more on creating more diverse cocoa agroforests. This should rely less on costly inputs, and incorporate a range of crops and forest products that aim to produce a more stable and diverse agroecosystem that is less prone to disease and pests, and provides a wide range of income-generating resources. The affinity of cocoa to forest conditions provides a crop with the potential to adapt and thrive within diverse agroforests with lower applications of external inputs (Schroth and Harvey, 2007). 


\section{CONCLUSION}

Examining the development of cocoa from a longterm perspective provides a broad perspective in which to examine agricultural commercialisation, particularly in understanding the linkages between ecology, technology, capital accumulation and intensification. Pressures for intensification have arisen from two factors: scarcity of land and rising costs of production. Two distinct phases can be identified in the development of cocoa; pioneer frontier development characterised by extensive cultivation of cocoa and rapid settlement of new forests, and intensification of production in old frontier areas to rehabilitate cocoa and cope with the mounting costs of production. Agricultural modernisation has not been able to solve the ultimate symptoms of the crisis of production in old frontier zones, which are manifest in disease problems.
It has resulted in farmers expending increasing resources on agrochemicals that prevent them for investing in other inputs including fertilisers. The high labour requirements in farming in old frontier districts also prevent farmers from being able to follow technical recommendations. The high cost of production and fluctuating price cycles undermine the investments of large farmers seeking to maximise profits through expansion. They also create barriers of entry for small farmers struggling to gain access to land and to afford the high costs of labour and inputs. Thus, there is little evidence in the cocoa sector of the emergence of a significant stratum of medium-scale farmers using modern technology, but overwhelming evidence of large numbers of impoverished smallholders who cannot afford to acquire modern technology. 


\section{REFERENCES}

Amanor, K.S. (1994) The New Frontier: Farmers' responses to land degradation. A West African case study. London: Zed Books.

Austin, G. (2005) Labour, Land and Capital in Ghana: From Slavery to Free Labour in Asante (1807-1956). Woodbridge: Boydell and Brewer Ltd.

Boafo, J. and Lyons, K. (2019) 'Expanding Cashew Nut Exporting from Ghana's Breadbasket: A political ecology of changing land access and use, and impacts fro local food systems', International Journal of Sociology and Agriculture and Food, 25(2): 152-172.

Collingwood, C.A. (1971) Cocoa Capsids in West Africa. Report of the International Capsid Research Team 196571. London: International Office of Cocoa and Chocolate Alliance.

Danquah, F.K. (2003) 'Sustaining a West African Cocoa Economy: Agricultural science and the swollen shoot contagion in Ghana, 1936-1965', Journal of African Economic History 31: 43-74.

Gockowski, J. and Sonwa, D. (2011) 'Cocoa Intensification Scenarios and their predicted impact on CO Emissions: Biodiversity conservation and rural livelihoods in the Guinea rainforest of West Africa', Environmental Management 48(2): $7-21$.

Hill, P. (1963) The Migrant Cocoa-Farmers of Southern Ghana: A Study in Rural Capitalism. Cambridge: Cambridge University Press.

Odijie, M. (2018) 'Sustainability Winners and Losers in Business-biased Cocoa Sustainability Programmes in West Africa', International Journal of Agricultural Sustainability, 16(2): 214-227.

Padi, B. and Owusu, G.K. (1998) 'Towards an integrated pest management for sustainable cocoa production in Ghana', in: Proceedings of the 1st Sustainable Cocoa Workshop, 20 March to 3 April 1998, Panama. Available at: https://nationalzoo.si.edu/scbi/migratorybirds/research/cacao/padi.cfm (Accessed: 1 November 2021).

Ruf, F. (2010) 'From Forest Rent to Tree-Capital: Basic 'laws' of cocoa supply', in: F. Ruf and P.S. Siswoputranto (eds.) Cocoa Cycles: The economics of cocoa supply, Great Abington, Cambridge: Woodhead Publishing Ltd.

Schroth, G. and Harvey, C.A. (2007) 'Biodiversity Conservation in Cocoa Production Landscapes: An overview', Biodiversity and Conservation 16(8): 2237-2244.

Yaro, J.A. (2010) 'Customary Land Tenure under Siege: Contemporary access to land in Northern Ghana', GeoJournal 75(2): 199-214. 
Amanor, K., Yaro, J. and Teye, J. (2022) Long-Term Change, Commercialisation of Cocoa Farming, and Agroecosystems and Forest Rehabilitation in Ghana. APRA Working Paper 80. Brighton: Future Agricultures Consortium.

(c) APRA 2022

ISBN: 978-1-78118-906-1

DOI: 10.19088/APRA.2022.002

\section{(c) BY-NC-ND}

This is an Open Access report distributed under the terms of the Attribution-Non Commercial-No Derivs 4.0 Unported (CC BY-NC-ND 4.0) Attribution - You must give appropriate credit, provide a link to the license, and indicate if changes were made. You may do so in any reasonable manner, but not in any way that suggests the licensor endorses you or your use. NonCommercial — You may not use the material for commercial purposes. NoDerivatives - If you remix, transform, or build upon the material, you may not distribute the modified material. You are free to: Share - copy and redistribute the material in any medium or format.

https://creativecommons.org/licenses/by-nc-nd/4.0/legalcode

If you use the work, we ask that you reference the APRA website (www.future-agricultures.org/apra/) and send a copy of the work or a link to its use online to the following address for our archive: APRA, Future Agricultures Consortium, University of Sussex, Brighton BN1 9RE, UK (apra@ids.ac.uk)

All APRA Working Papers go through a review process before publication.

\section{Cc) creative}

\section{DO YOU HAVE COMMENTS ON THIS PAPER?}

We would welcome your feedback on this working paper!

To provide brief comments, please follow this link to our short APRA Working Paper Feedback form: https://goo.gl/forms/1iVnXhhrIGesfR9

Agricultural Policy Research in Africa (APRA) is a programme of the Future Agricultures Consortium (FAC) which is

generating new evidence and policy-relevant insights on more inclusive pathways to agricultural commercialisation in sub-Saharan Africa. APRA is funded with UK aid from the UK Foreign, Commonwealth \&

Development Office (FCDO) and will run from 2016-2022.

The APRA Directorate is based at the Institute of Development Studies (IDS), UK (www.ids.ac.uk), with regional hubs at the Centre for African Bio-Entrepreneurship (CABE), Kenya, the Institute for Poverty, Land and Agrarian Studies (PLAAS), South Africa, and the University of Ghana, Legon. It builds on more than a decade of research and policy engagement work by the Future Agricultures Consortium (www.future-agricultures.org) and involves more than 100 researchers and communications professionals in Africa, UK, Sweden and USA. 